\title{
RADIOLOGY AND THE ARMY MEDICAL SCHOOL
}

\author{
- Colonel K. H. HARPER \\ M.R.C.S., D.M.R.D.
}

Adviser in Radiology

THE Army Medical School was already 35 years old when Roentgen published his paper "On a new form of radiation" in December 1895, mentioning inter alia the production of shadow photographs of the bones of the hand. The apparatus he used was normal physics research apparatus, available in most laboratories throughout the world, consisting essentially of a Crookes tube and an induction coil. Radiology thus sprang into being fully armed, and within a few days the experiments were repeated and confirmed universally. The new " all-seeing rays " were featured in the popular press, in Punch and on the Music Hall stage. The British Medical Journal printed articles on radiographs on 18th January, 1896, with a leading article on the same subject on 1st February. Most of the early articles described bony abnormalities and metallic foreign bodies, but included Customs examination of parcels.

The Army Medical School was fairly early in the field. In a latter dated 16th April, 1896, Surgeon Lieutenant-Colonel W. F. Stevenson, M.B., Professor of Military Surgery, applied for a grant of $£ 25$ " for the purpose of purchasing the apparatus necessary for photographs by means of Rontgen X-Rays." He does not appear to have waited patiently for his grant, since the B.M.J. of 25 th April contains an article by Mr. Rowlands, an acknowledged authority on this subject, from which the following extracts are taken " At Netley Hospital I attended on the invitation of Surgeon Colonel Stevenson and gave a demonstration of the process, and skiagraphed the case above mentioned" (a case of femoral condyle fracture). "The authorities of the Army Medical Department are taking active steps to introduce the new method into use in the approaching African Expedition (i.e. the Dongola expedition against the Dervishes). The value of the method for the discovery of bullets is undisputed." That Colonel Stevenson's own apparatus did arrive in 1896 is proved by his annual list of operations for this year, in which he states, "the necessary apparatus for skiagraphy has been supplied to the Army Medical School and has given satisfactory results" and describes cases of lodged bullet and bone injury in which the diagnosis " has been rendered easy and certain." His studies of the subject were not parochial, as in August 1897 he attended a Congress in Moscow reporting on five skiagraphs shown by a German military surgeon, noting a little enviously the large coil and tube used. His next list for '97-98 refers to his " powerful coil giving an 18-inch spark, Cossar's Osmium tube and a large German tube." It thus appears the Professor was keeping his apparatus well up to date. In addition to the medical aspect of skiagraphy he also writes penetrating assessments of the difficulties of power supplies in the field and the transportability of apparatus in general. The continued contact of the School with the leaders of radiology is shown by the visit of Mr. Mackenzie Davidson 
of Charing Cross Hospital to Netley early in 1898 to demonstrate his apparatus and method of localizing foreign bodies. "Mr. Davidson' himself localized the bullet in the pelvis of L-Cpl. E. The bullet, near the SI joint, was successfully extracted and the patient later returned to duty." Our Professor, however, not content with second-hand casualties, left for South Africa in October 1899, taking apparatus with him, rather characteristically expending a further $£ 518 \mathrm{~s}$. $3 \mathrm{~d}$. on various items, and left the Assistant Professor to settle the bill as best he could.

Development of field service apparatus was not without outside stimulus and interest, as-is shown in the Lancet for May 1898 when a Question in the Commons on 2nd May is reported, asking whether X-ray apparatus has been dispatched to Egypt. The Secretary is able to answer that sets were dispatched on 5th April. At first the new technique was part of ordinary School instruction, but the technical difficulties of keeping the apparatus working soon demanded some degree of specialization. The first special trainee I have traced is in a. War Office letter dated 17th November, 1897, " Permission is given by the Under Secretary of State for Surg. Lt. W. E. Huddleston A.M. Staff to proceed from Aldershot to Netley, for instruction in the use of the Røntgen apparatus, and I am to request that you will be so good as to cause him to be recognized accordingly." Special short courses were thereafter organized and a letter of 3rd October, 1898, submits a list of four officers qualified in the use of the Rœntgen Ray Apparatus. The use of radiography in Field Hospitals of most modern armies was well developed by the end of 1897, being reported from the North-West Frontier of India, the Turko-Greek War and the Spanish-American War. In the taking of Santiago (Cuba) in 1898 the United States Chief of Operating Staff took a civilian specialist in skiagraphy with him, and is enthusiastic about results. Training in the necessary technique was widely available, and the Indian Medical Gazette in December 1899 refers to the X-ray classes available at the new Polytechnic.

After the Boer War the School, now in London and re-named the College, continued its skiagraphic courses under the control of Surgeon-General .W. F. Stevenson, C.B., who remarks in the Journal of August 1903, " The figures are reproductions of skiagrams of cases met with in South Africa, and these could be added to in large numbers from the collection in the College." Certificates of competence in skiagraphy had been issued since 1897, but in 1903, the reorganized course for promotion allowed the selection by candidates of special subjects if they so desired. There appears to have been no limit on the number of "specials" one took, some officers securing as many as three. The pass list for January 1904 shows that of 27 candidates, no less than five took the special course of skiagraphy. The attitude to specialization was different, all officers being required to perform a wide scale of general medical, surgical and regimental duties, perhaps typified by the Professor of Military Surgery, who before obtaining this appointment was Assistant Professor of Military Medicine. Further evidence is obtained from the List of June 1905 which shows three "skiagraphists" employed as follows:-one as Company Officer, Gibraltar; another as Bacteriologist and Anæsthetist, Valletta; the third as Adjutant, Manchester Company R.A.M.C. (Volunteers). Lest it be thought this system applied only to skiagraphists, I hasten to add Captain P. Evans, M.B., holding the D.P.H. and special certificates 
in Operative Surgery and Specific Fevers, employed as Company Officer, No. 2 Company, Aldershot.

During the period 1902-1914, the College facilities for radiological training appear to have been excellent technical instruction by a technician at the Queen Alexandra Military Hospital and the routine lectures of the general course. Special studies were made at the student's own arrangement at civilian hospitals, though it appears likely that many candidates for " specials" had completed their studies before being called forward for their course. Certainly candidates for operative surgery did courses in Indian civil hospitals and the Universities of Calcutta, Bombay and Madras before coming home. The period of more extreme specialization appears to have started in India in 1909 when the Indian Medical Service opened an X-ray Institute in Dehra Dun, and awarded a specialist qualification in "Electrical Science" after a short but intensive course. Some British Service officers attended this course, presumably with a view to their later promotion examination. In February 1910 D. B. McGrigor, R.A.M.C., attended this course, later being Brigadier and Consultant in Radiology in the '39-45 War.

Up to 1913, technical advances were small keeping the subject readily comprehensible. The invention of the Coolidge (Hot Cathode) Tube in 1913 enormously increased the range and quality of examination, and quickly brought the available information up to a full-time specialty. Owing to war conditions the tube was not much exploited in the United Kingdom until 1916, and its full impact not felt until nearly 1920. During the '14-18 War years the chief military problem wás supply of apparatus. The X-ray Section was moved to the Imperial Institute, South Kensington, and toward the end of the war virtually controlled apparatus production in this country. After the war, the Diploma in Radiology of the University of Cambridge was instituted and set a new standard. The R.A.M.C. courses for promotion in 1920 introduced this new concept of specialism and the first qualified British Army Radiologist was the D. B. McGrigor mentioned earler. He was posted to the Queen Alexandra Military Hospital, Millbank, and there conducted and controlled all specialist training in this subject up to 1939 . He always insisted that the training was only nominally under the Professor of Surgery, who gave him a free hand.

In 1940, the supply of Radiologists for the Army from civil sources ran out, and a School of Radiology and Radiography was organized within the College, complete with varied $X$-ray sets, film library and a separate staff. Lacking sufficient patients the students radiographed anything available, including each other, and studied films collected from many other hospitals. The qualification awarded was a "grading" which could be later converted to "specialist" after experience and recommendation. This school produced 60 radiologists and 1,000 radiographers, not counting students from our Dominions and Allies. Experiments in Mass Miniature Radiography were planned and executed from this School, in co-operation with the Ministry of Health. This School continued at a lesser tempo after the war, still in the College buildings until 1950, when it moved to the Royal Herbert Hospital, Woolwich, where it still remains, principally as a school for radiographers.

The role of the College in Radiology since 1948 has been the organization of radiological study at civilian establishments, with a view to the D.M.R.(D.) being 
the basic qualification for an Army specialist. This I feel is the proper function of the College in future, that is to say, to ensure that the Army Specialist is in no way inferior in qualification to his civilian counterpart.

It is my pleasure to acknowledge the help given me by Mr. M. Davies, the College Librarian, who supplied a list of references and directed my attention to where further material might be found. Only works available in the College Library were used in this article.

\section{SOURCES}

Minutes of Senate, Army Medical School, 1896.

Copies of Correspondence, Army Medical School.

Appendices to Reports on the Health of the Army, 1895-97.

J. roy. Armv med. Cps., 1903, 1905, 1917 and 1948.

The following have been elected Fellows of the Royal College of Physicians of London:

Lieutenant-General W. A. BURKI, C.B.E., M.D. (St. Andrews), DirectorGeneral Medical Services, Ministry of Health; Labour and Social Welfare, Government of Pakistan.

Major-General C. C. KAPILA, O.B.E., M.B. (Rangoon), Indian Army Medical Corps. Commandant, Armed Forces Medical College, Poona.

Doctor Alan BARHAM CARTER, M.D., D.P.M., M.R.C.P. 